How to cite: Milian, N., Reckerth, D.U., Mitea, A.M., Blaga, I.C., Harpa, G.V. (2021) Favorable Avalanche Triggering Conditions and Risk During 2019-2020 Winter. 2021 "Air and Water - Components of the Environment" Conference Proceedings, Cluj-Napoca, Romania, p. 201-208, DOI: 10.24193/AWC2021_19.

\title{
FAVORABLE AVALANCHE TRIGGERING CONDITIONS AND RISK DURING 2019-2020 WINTER
}

\author{
Narcisa MILIAN ${ }^{1}$, Dorian Udo RECKERTH ${ }^{1}$, Adela Mariana MITEA ${ }^{1}$, Ioana \\ Cristina BLAGA ${ }^{1}$, Gabriela Victoria HARPA ${ }^{1}$ \\ DOI: 10.24193/AWC2021_19
}

\begin{abstract}
The paper presents and analyzes the variations of meteorological and specific snow parameters which favored the onset of avalanches in the winter season 2019-2020 in the mountains monitored by the Snow and Avalanche Program of the National Meteorological Administration, taking also into account the estimated avalanche risks for each massif. The analyzed parameters are those measured during the daily observations and weekly measurements at the meteorological stations Bâlea-Lac, Vârful Omu, Sinaia, Predeal, Parâng, Țarcu, Semenic, Vlădeasa, Iezer, Călimani, Ceahlău, as well as during some measurement campaigns outside the meteorological stations area. Avalanche cases and favorable conditions for their triggering are included in a database, to be analyzed and used to better estimate the avalanche risk and reduce their effects on the environment and people. The favorable conditions for triggering the avalanches were due to both significant snowfall, high temperature values or their sudden increase, as well as the transformations that take place inside the snow layer, as a result of which unstable structures are formed.
\end{abstract}

Keywords: avalanche, ground pressure, temperature, snowfall

\section{INTRODUCTION}

Nivological 2019-2020 season started on November 20, 2019, at all eleven stations within snow measurements program; Sinaia $(1510 \mathrm{~m})$, Predeal $(1090 \mathrm{~m})$, Vârful Omu (2504 m), Bâlea-Lac (2050 m), Ceahlău Toaca (1897 m), Călimani (2022 m), Iezer (1785 m), Vlădeasa 1800 (1836 m), Ţarcu (2180 m), Semenic (1370, Parâng $(1548 \mathrm{~m})$, covering most of the mountains exposed to avalanche risk in the Romanian Carpathians (Fig.1). The observation program took place until April 30, 2020 at Predeal, Sinaia 1500, Parâng, Semenic, Țarcu, Vlădeasa, Iezer, Călimani, May 10, 2020 at Ceahlău-Toaca and June 10, 2020, at Bâlea-Lac and Vârful-Omu meteorological stations (Bilanțul nivologic al sezonului de iarnă 2019-2020).

During 2019-2020 winter, 45 avalanches were reported by meteorological stations involved in the nivological program and by external observers (Milian et al, 2020): 1 avalanche in November, 4 in December, 3 in January, 5 in February, 13 in March, 10 in April, 8 in May and 1 in June (Fig. 2). Of these, most were reported by Bâlea-Lac station (30), in the Făgăraș massif, 10 in the Bucegi massif, 2 in Țarcu massif, 2 in the Rodna massif and 1 avalanche in the Călimani massif (Fig. 2).

1 SRPV Sibiu, CMR Transilvania-Sud, 550003 Sibiu, Romania; e-mail: narcisa.milian@gmail.com, 
Among the recorded avalanche cases, one had a dead victim - the avalanche from Șerbota Valley, Făgăraș Massif, on March 6, 2020.

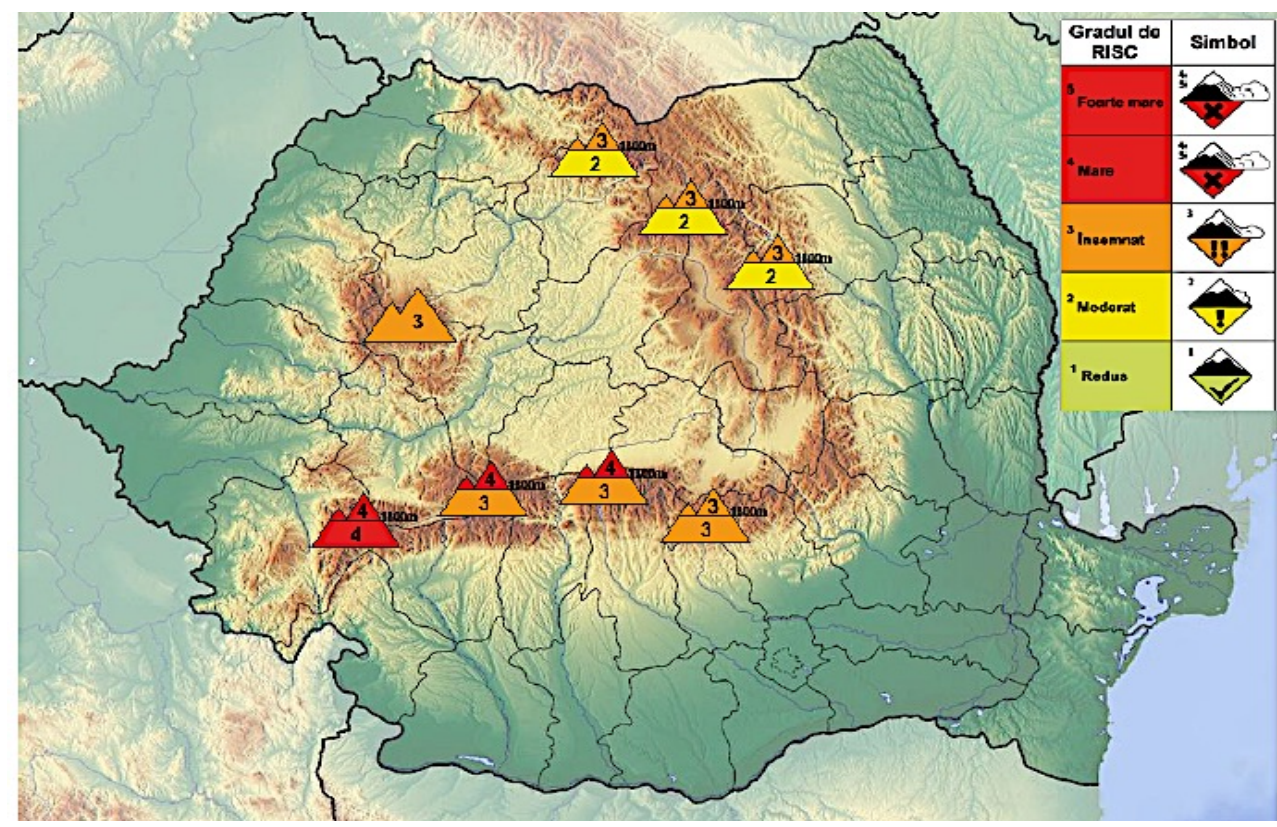

Fig. 1. Romanian nivological network

The period with the highest frequency of reported avalanches was February 28 to March 15, 2020, a period in which avalanches were reported in the Făgăraș, Bucegi, Țarcu, Călimani and Rodnei Massifs.
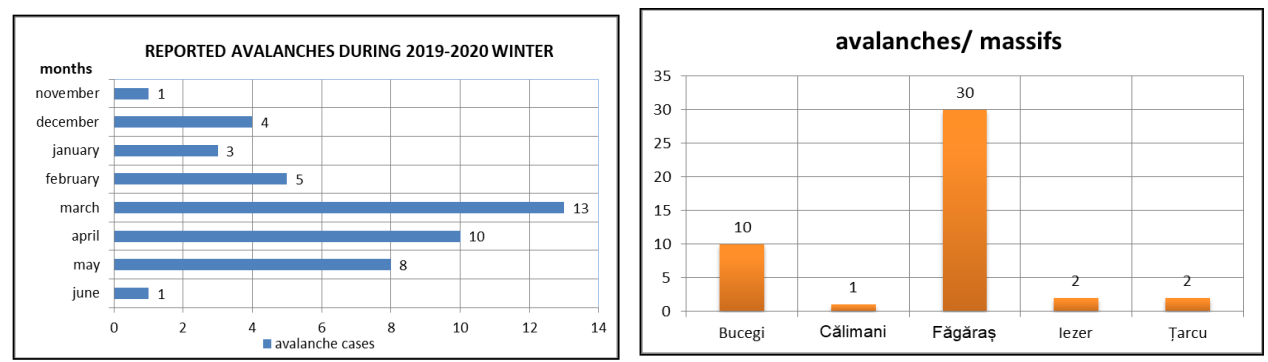

Fig. 2. Avalanches reported during 2019-2020 winter

Maximum snow thickness in the meteorological stations platform was recorded during March and April in the meteorological stations situated on high altitudes (over $2000 \mathrm{~m}$ ) and mostly in the Meridional Carpathians (Fig. 3). Thus, the highest value, of $236 \mathrm{~cm}$, was registered at Bâlea-Lac on April 1, 2020. At the other stations, the values were below $100 \mathrm{~cm}$, with maximums of $92 \mathrm{~cm}$ at Călimani (23.03), $78 \mathrm{~cm}$ at Semenic (22.02), $72 \mathrm{~cm}$ at Vârful Omu (01.04), $58 \mathrm{~cm}$ at Parâng (24.03), $46 \mathrm{~cm}$ at Sinaia (24.03), 
$43 \mathrm{~cm}$ at Ceahlău (28.02), $41 \mathrm{~cm}$ at Țarcu (11.03), $41 \mathrm{~cm}$ at Predeal (30.12), $40 \mathrm{~cm}$ at Vlădeasa (30.12) and $29 \mathrm{~cm}$ at Iezer (29.02), the lowest (Fig. 3) (Baza de date a ANM).

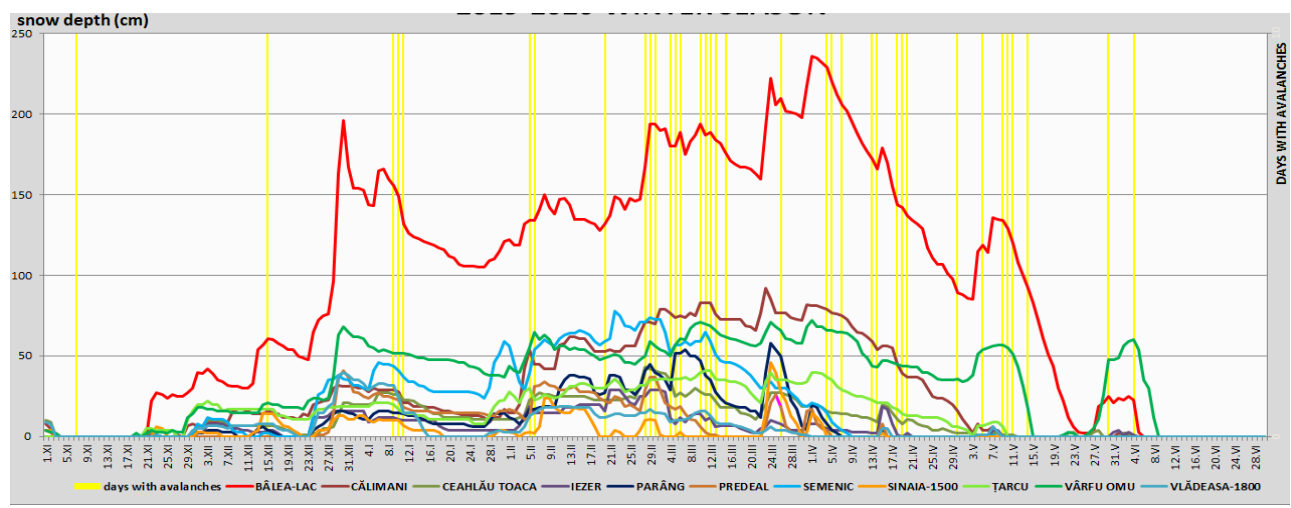

Fig. 3. 2019-2020 winter season - Snow layer variation and days with avalanche records at all the meteorological stations within nivological program

The estimated avalanche risk for the days with recorded avalanches was usually considerable (3) - in 20 days, then moderate (2) - in 10 days and 2 avalanches took place in a high risk situation (4).

Of the 45 avalanche recorded cases, some happened in the same day, thus the number of days with avalanche cases was only 36 (Fig. 4) (Buletinele nivometeorologice, 2019-2020).

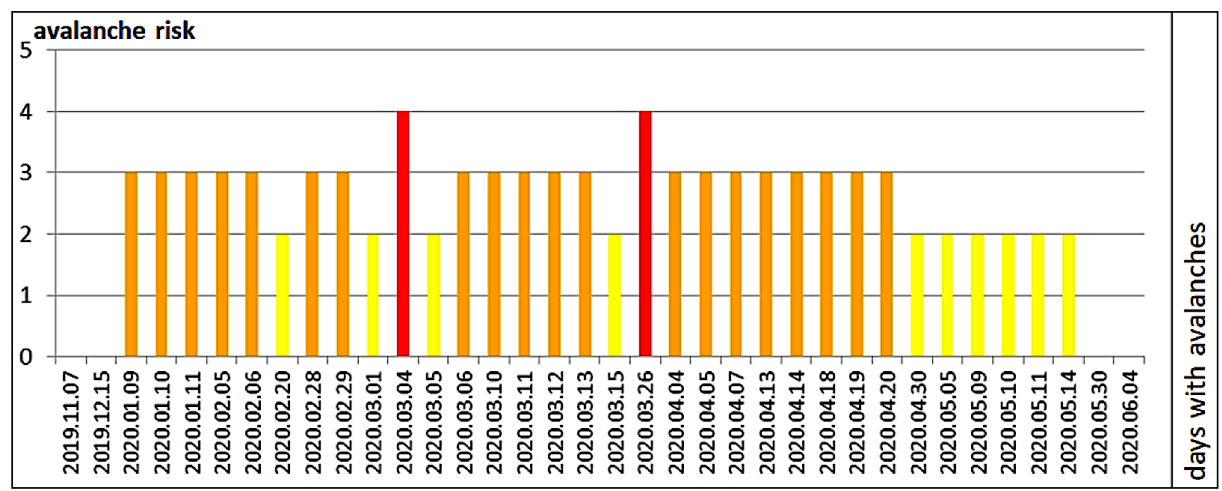

Fig. 4. Days with recorded avalanches and estimated risk

\section{DATA AND METHODS}

In the paper, we tried to find correlations between the reported avalanches and meteorological parameters measured by meteorological stations, evolution of the snow layer and synoptic situations that favoured the accumulations of precipitation with unstable potential.

We decided to monitor in more detail the period of February 24 to March 15, 2020, because, starting with February 24, a series of Icelandic Cyclones were reported, that 
generated significant snowfalls in all massifs, interspersed with warm and sunny periods. We represented the snow layer evolution, together with the most important meteorological parameters (maximum and minimum temperatures, cloudiness, amounts of recorded precipitation, wind, reported meteorological phenomena) at the meteorological stations within the nivological program. Also, the synoptic evolution of the the period was analyzed, the characteristics of the air masses and the favorable structure that led to the risk situations in the monitored massifs. The data are taken from the National Administration of Meteorology Base Date and daily nivological bulletin, and the synoptic maps from Deutscher Wetterdienst archive, on internet.

\section{SNOW AND METEOROLOGICAL PARAMETERS EVOLUTION}

In the figures below, we represented the evolution of precipitation and snow cover, snow characteristics, minimum and maximum temperatures, recorded phenomena, nebulosity and wind gusts at Bâlea-Lac, Vârful Omu, Sinaia, Țarcu, Călimani and Iezer meteorological stations, using Gelinivw software archive.

The graphics show important snow accumulation, as well as alternation of colder with warmer periods, favoring snow melting and surface moisture, thus increasing the risk of triggering avalanches (Fig. 5-9).

Four periods were identified within the chosen interval: February 24-29, March 1-5, March 6-10 and March 11-16 - (Fig. 5-9)

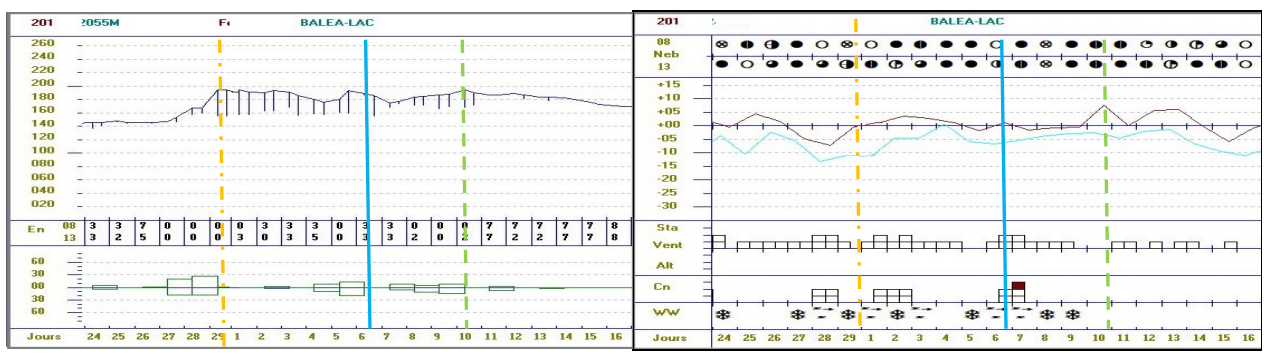

Fig. 5. Evolution of meteorological parameters during 24.02-16.03 at Bâlea-Lac En $=$ Snow type, Jours $=$ Days, Neb $=$ Nebulosity, Vent $=$ Wind $(\operatorname{speed}, m / s)$,

Cn $=$ wind on altitude, $W W=$ current weather

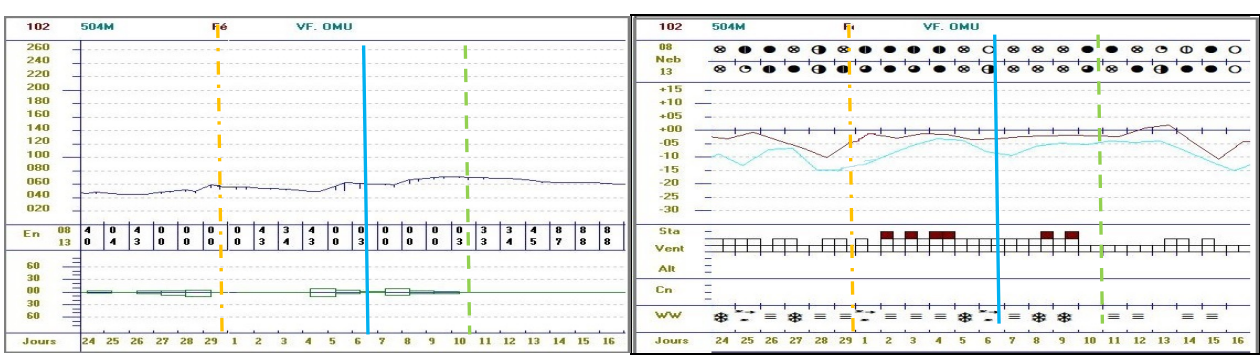

Fig. 6. Evolution of meteorological parameters during 24.02-16.03 at Vârfu Omu

En $=$ Snow type, Jours $=$ Days, Neb $=$ Nebulosity, Vent $=$ Wind $(\operatorname{speed}, m / s)$, $C n=$ wind on altitude, $W W=$ current weather 


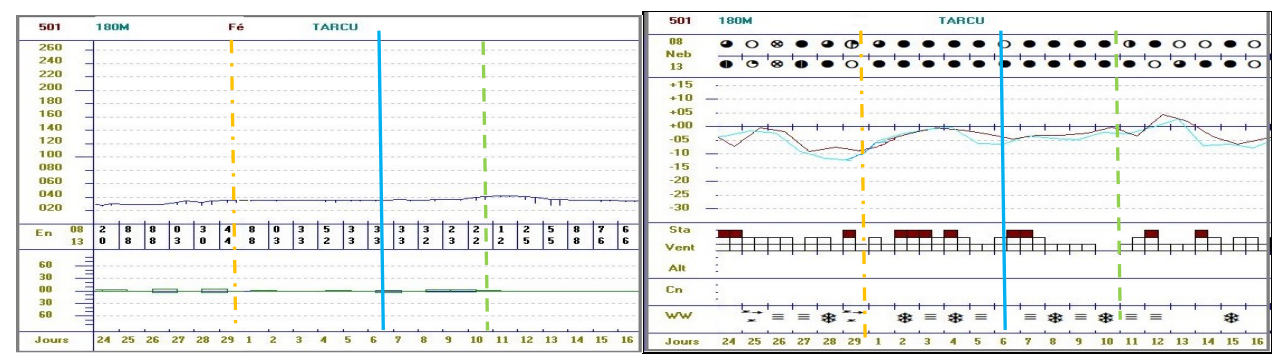

Fig. 7. Evolution of meteorological parameters during 24.02-16.03 at Tarcu En $=$ Snow type, Jours $=$ Days, Neb $=$ Nebulosity, Vent $=$ Wind $(\operatorname{speed}, \mathrm{m} / \mathrm{s})$, Cn $=$ wind on altitude, $W W=$ current weather
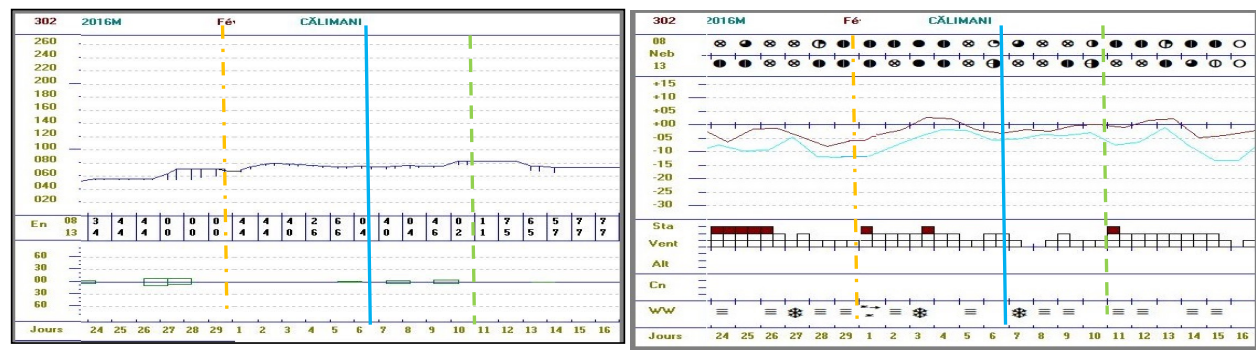

Fig. 8. Evolution of meteorological parameters during 24.02-16.03 at the Călimani En $=$ Snow type, Jours $=$ Days, Neb $=$ Nebulosity, Vent $=$ Wind $(\operatorname{speed}, m / s)$, Cn $=$ wind on altitude, $W W=$ current weather

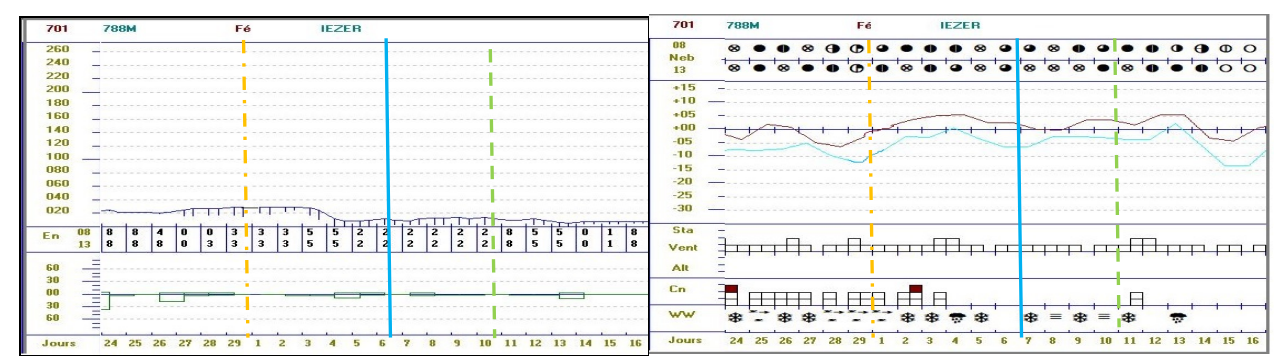

Fig. 9. Evolution of meteorological parameters during 24.02-16.03 at Iezer En $=$ Snow type, Jours $=$ Days, Neb $=$ Nebulosity, Vent $=$ Wind $(\mathrm{speed}, \mathrm{m} / \mathrm{s})$, Cn $=$ wind on altitude, $W W=$ current weather

\section{SYNOPTIC SITUATION}

Between February 24 and 29, a short-wave altitude trough (February 24) and a deeper one (February 26-29) followed one another, being associated to frontal systems, which brought consistent precipitation in the mountain area and determined snow depth increase, especially in the last days of the month (Fig. 10) and Făgăraș Massif (Fig. 5). 
The temperatures were relatively high before and after the passage of the shortwave trough (February 24th), followed by a cooling with the installation of the trough from February 26-29. Two avalanches were reported in Făgăraş, due to the important accumulations of fresh snow (increase of $50 \mathrm{~cm}$ measured at Bâlea-Lac station - Fig. 5).
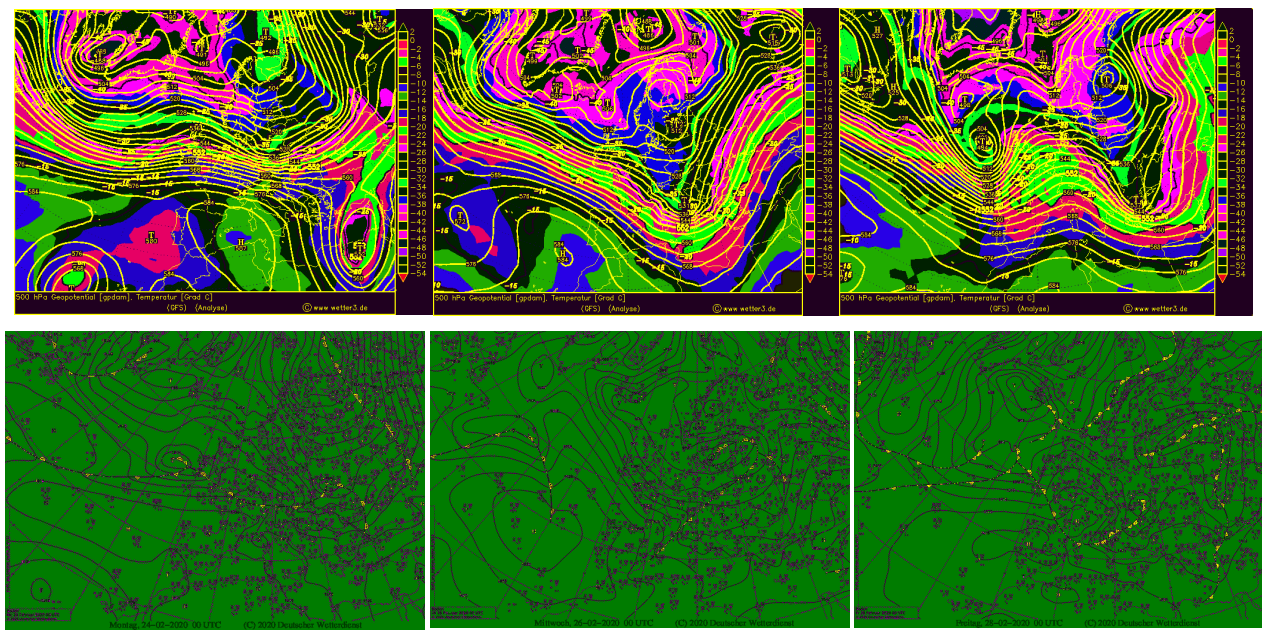

Fig. 10. 2020.02.24, 26, 28, 00 UTC; 500 hPa geopotential and temperature, GFS numerical model - analysis. Ground-level pressure and frontal systems, Deutscher Wetterdienst (DWD)

The first 5 days of March brought a warm weather (Fig. 5-9), because of an altitude ridge persistance over Romania (Fig. 11). On higher altitudes, there have been wind intensifications, that favoured the formation of wind slabs and some melting avalanches in Rodnei, Călimani, Țarcu and Făgăraș Massifs. The warm weather caused the newly deposited snow layer to harden at its top, which favored the displacement of the unstable layer and its sliding over the older, compacted layers, over which it slipped easily.
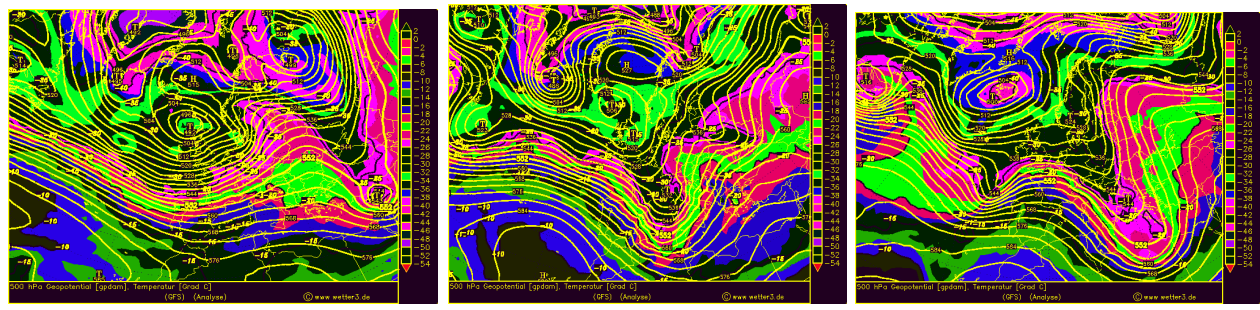

Fig. 11. 2020.03.01, 03, 05, at 00 UTC: 500 hPa geopotential and temperature, GFS numerical model reanalysis, (DWD)

Between March 6 and 10, two cold fronts passed over Romania, with associated Icelandic troughs (Fig. 12), which brought an accentuated weather cooling and wind intensifications, associated with significant amounts of precipitation (Fig. 5-9). 

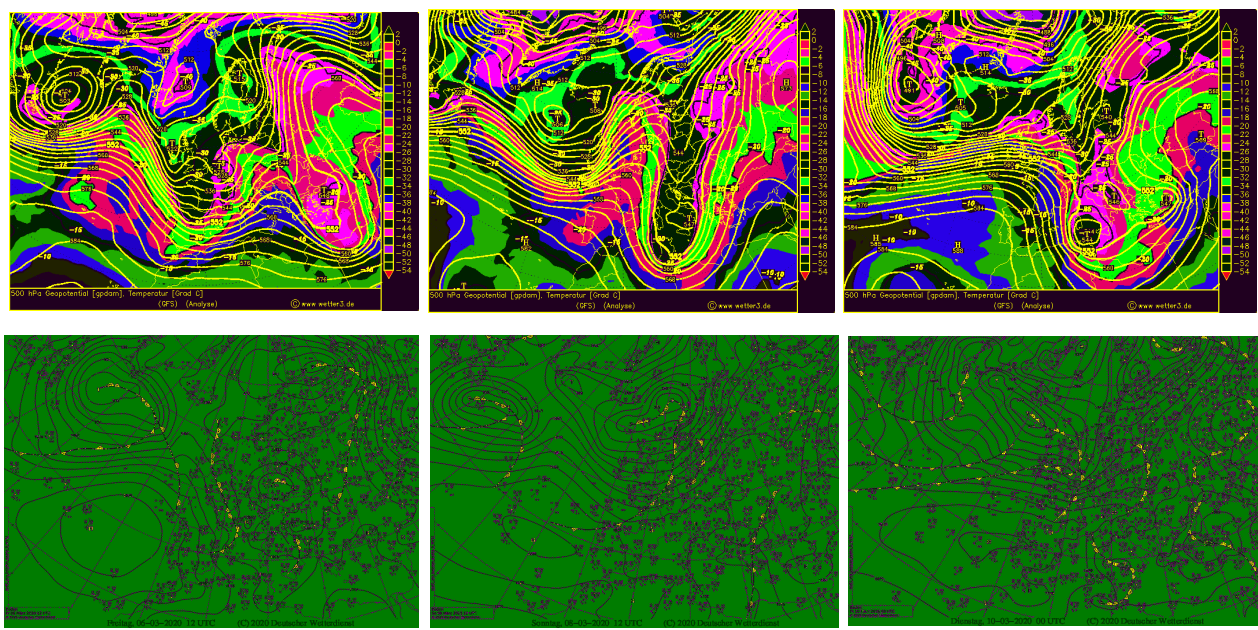

Fig. 12. 2020.03.06, 08, 10, at 00 UTC - $500 \mathrm{hPa}$ geopotential and temperature, GFS numerical model - analysis. Ground-level pressure and frontal systems, (DWD)

From the second part of March 10 until March 15, a new ridge dominated on 850 and $500 \mathrm{hPa}$ levels (Fig. 13), bringing again a weather warming, with positive values of most maximum temperatures and even some minimum ones (Fig. 5-9) and a series of melting avalanches in the Făgăraş, Bucegi, Țarcu and Rodnei massifs. The first days also brought sustained intensifications of the wind at high altitudes in the mountains (Fig. 5-9).
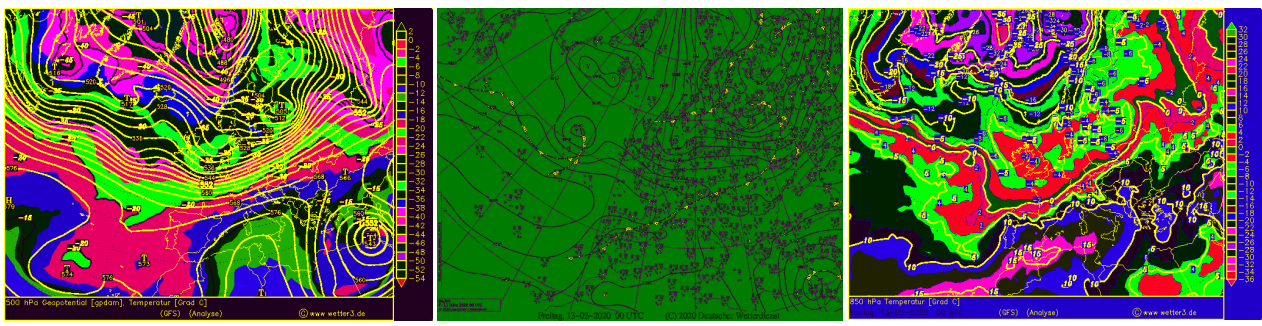

Fig. 13. 2020.03.06, 08, 10, at $00 \mathrm{UTC}-500$ and $850 \mathrm{hPa}$ geopotential and temperature, GFS numerical model - analysis. Ground-level pressure and frontal systems, (DWD)

\section{CONCLUSIONS}

We highlighted this interval, from the 2019-2020 winter, due to the numerous avalanches observed in several massifs, probably much less than those that happened, mostly unobserved or unreported. The first feature to be noted is that one of the first, more consistent snowfalls, from February 26 to 29, came after a warmer period (February 24-25) with partial insolation and positive temperatures below $2000 \mathrm{~m}$ in most massifs and very close to 0 degrees on the ridges.

These combined factors caused the important snow amounts of February 26-29 to fall on a former wet and then frozen snow, so in most cases, on an ice crust, which led to a poor cohesion between the freshly deposited layer and the old snow. Thus, the 
newly deposited layer was extremely unstable, and any external stimulus, even of low intensity, could be the trigger that leads to the movement of the entire unstable mass.

This triggering factor can be, in these cases, spontaneous - like the weight of the newly deposited layer which has no grip with the old, frozen layer, covered by an ice crust, one or several tourists (like in the avalanche from S,erbota), a broken cornice, or insolation accompanied by slightly positive temperatures.

In fact, insolation and warm weather caused most of the avalanches during this period. They led to the wetting of the powder layer in the upper part, which easily broked the powdered snow below, which was like a pillow of air over which the denser layer up slipped easily.

Another important conclusion is that the alternation of cold, snowy periods with warm and sunny ones, may be an indication of the increased risk of avalanches, especially in areas where the newly deposited layer is more consistent, exceeding in some places $30 \mathrm{~cm}$ and thus ensuring a sufficiently large mass that can be gravitationally engaged by a triggering factor.

Another important factor worth mentioning is the intense wind, which can accompany the snowfall, or can blow over a freshly deposited snow and which, in conditions of negative temperatures, will easily create extremely unstable wind slabs on sheltered slopes for a period of few days and which can easily break when overloaded with tourists or cornice detached from the ridges.

All these factors were met during this period, when the estimated avalanche risk had values from 2 to 4 in the bulletins issued by the National Meteorological Administration.

\section{REFERENCES}

1. ***, Bilanţul nivologic al sezonului de iarnă - publicaţie anuală, ANM, Bucureşti

2. $* * *$, Buletinul nivometeorologic - arhiva, SRPV Sibiu

3. Deutscher Wetterdienst (DWD), http://www.wetter3.de, accesed on January 10, 2020

4. ANM data base (Baza de date a ANM)

5. Gelinivw archive, ANM

6. Esteban P. \& al. (2005), Atmospheric circulation patterns related to heavy snowfall days in Andorra, Pyrenees, International Journal of Climatology,25,3,319-329.

7. Hansen C., Underwood S.J, (2012), Synoptic Scale Weather Patterns and Size-5 Avalanches on Mt. Shasta, California, Northwest Science, 86, 329-341

8. Milian, N., Blaga C., Mitea A., Harpa G., Reckerth U., (2020), Analiza sezonului nivologic 2019-2020, Sesiunea ANM 